\title{
Cervical Spondylotic Myelopathy Secondary to Ochronotic Vertebral Arthropathy
}

Wladimir Bocca Vieira de Rezende Pinto, MD, MSc, Igor Braga Farias, MD, Bruno de Mattos Lombardi Badia, MD, José Marcos Vieira de Albuquerque Filho, MD, Roberta Ismael Lacerda Machado, MD, Paulo Victor Sgobbi de Souza, MD, and Acary Souza Bulle Oliveira, MD, PhD

Neurology ${ }^{\circledR} 2021 ; 96: 627-628$. doi:10.1212/WNL.0000000000011663

Figure Examination and Neuroimaging in Alkaptonuria

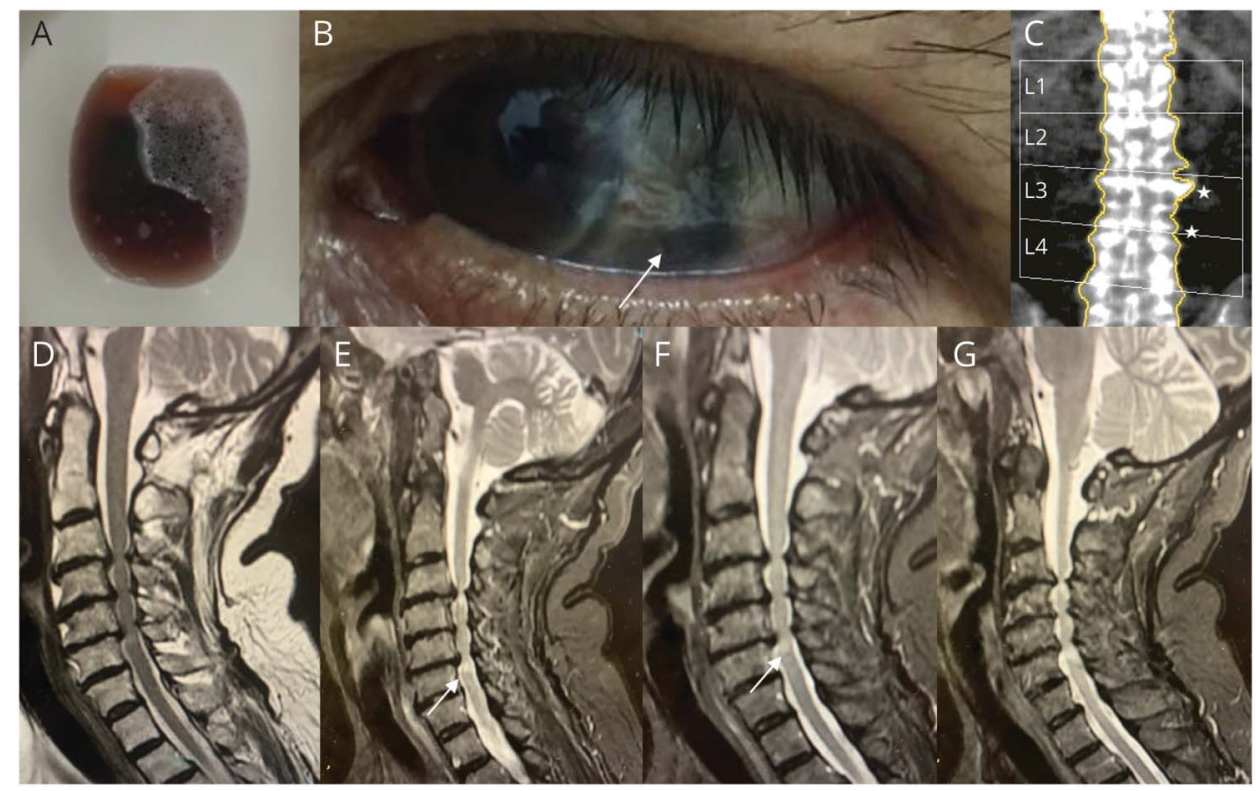

(A) Dark urine and (B) dark sclerae (white arrow). (C) Bone densitometry disclosing osteopenia and increased density in intervertebral lumbar disks. (D-G) Sagittal spine MR imaging showing severe osteoarthropathy, disk herniation at C3-C6 levels, cervical stenosis and hyperintense spine change in T2-weighted sequence (white arrow).

A 39-year-old man presented with progressive gait disturbance and urinary incontinence. Medical history disclosed nephrolithiasis, dark urine, osteopenia and osteoarthrosis for 15 years. Examination disclosed crural spastic paraparesis with sensory level at T1 and hyperpigmentation of the sclerae (figure). Neuroimaging studies disclosed cervical spondylotic myelopathy and several discs prolapses. Homogentisic acid levels by HPLC were high in 24hour urine.

Alkaptonuria or inherited ochronosis is an autosomal recessive inherited metabolic disorder involving mainly the joints, cardiovascular and genitourinary systems. Dark urine and sclerae and diffuse osteoarthropathy represent clues for clinical suspicion. ${ }^{1,2}$ Early adult-onset cervical spondylotic myelopathy represents a severe neurologic complication. ${ }^{1,2}$

\author{
Correspondence \\ Dr. Pinto \\ wladimirbvrpinto@ \\ gmail.com
}

\section{Study Funding}

No targeted funding reported. 


\section{Disclosure}

The authors report no disclosures relevant to the manuscript. Go to Neurology.org/N for full disclosures.

\begin{tabular}{|c|c|c|}
\hline Name & Location & Contribution \\
\hline $\begin{array}{l}\text { Wladimir Bocca } \\
\text { Vieira de Rezende } \\
\text { Pinto, MD, MSc }\end{array}$ & $\begin{array}{l}\text { Federal University of } \\
\text { São Paulo (UNIFESP), } \\
\text { São Paulo, SP, Brazil }\end{array}$ & $\begin{array}{l}\text { Case report project } \\
\text { (conception, organization, } \\
\text { execution); Writing of the } \\
\text { first draft, review and } \\
\text { critique }\end{array}$ \\
\hline $\begin{array}{l}\text { Igor Braga Farias, } \\
\text { MD }\end{array}$ & $\begin{array}{l}\text { Federal University of } \\
\text { São Paulo (UNIFESP), } \\
\text { São Paulo, SP, Brazil }\end{array}$ & $\begin{array}{l}\text { Case report project } \\
\text { (conception, } \\
\text { organization, execution); } \\
\text { Writing of the first draft, } \\
\text { review and } \\
\text { critique }\end{array}$ \\
\hline $\begin{array}{l}\text { Bruno de Mattos } \\
\text { Lombardi Badia, } \\
\text { MD }\end{array}$ & $\begin{array}{l}\text { Federal University of } \\
\text { São Paulo (UNIFESP), } \\
\text { São Paulo, SP, Brazil }\end{array}$ & $\begin{array}{l}\text { Case report project } \\
\text { (conception, organization, } \\
\text { execution); Writing of the } \\
\text { first draft, review and } \\
\text { critique }\end{array}$ \\
\hline
\end{tabular}

Appendix (continued)

\begin{tabular}{|c|c|c|}
\hline Name & Location & Contribution \\
\hline $\begin{array}{l}\text { José Marcos } \\
\text { Vieira de } \\
\text { Albuquerque } \\
\text { Filho, MD }\end{array}$ & $\begin{array}{l}\text { Federal University of } \\
\text { São Paulo (UNIFESP), } \\
\text { São Paulo, SP, Brazil }\end{array}$ & $\begin{array}{l}\text { Case report project } \\
\text { (conception, organization, } \\
\text { execution); Writing of the } \\
\text { first draft, review and } \\
\text { critique }\end{array}$ \\
\hline $\begin{array}{l}\text { Roberta Ismael } \\
\text { Lacerda } \\
\text { Machado, MD }\end{array}$ & $\begin{array}{l}\text { Federal University of } \\
\text { São Paulo (UNIFESP), } \\
\text { São Paulo, SP, Brazil }\end{array}$ & $\begin{array}{l}\text { Case report project } \\
\text { (conception, organization, } \\
\text { execution); Writing of the first } \\
\text { draft, review and critique }\end{array}$ \\
\hline $\begin{array}{l}\text { Paulo Victor } \\
\text { Sgobbi de Souza, } \\
\text { MD }\end{array}$ & $\begin{array}{l}\text { Federal University of } \\
\text { São Paulo (UNIFESP), } \\
\text { São Paulo, SP, Brazil }\end{array}$ & $\begin{array}{l}\text { Case report project } \\
\text { (conception, organization, } \\
\text { execution); Writing of the first } \\
\text { draft, review and critique }\end{array}$ \\
\hline $\begin{array}{l}\text { Acary Souza Bulle } \\
\text { Oliveira, MD, PhD }\end{array}$ & $\begin{array}{l}\text { Federal University of } \\
\text { São Paulo (UNIFESP), } \\
\text { São Paulo, SP, Brazil }\end{array}$ & $\begin{array}{l}\text { Case report project } \\
\text { (conception); Review and } \\
\text { critique }\end{array}$ \\
\hline
\end{tabular}

\section{References}

1. Perrone A, Impara L, Bruni A, Primicerio P, Marini M. Radiographic and MRI findings in ochronosis. Radiol Med 2005;110:349-358.

2. Hendriksz CJ. Inborn errors of metabolism for the diagnostic radiologist. Pediatr Radiol 2009;39:211-220.

\section{Subspecialty Alerts by E-mail!}

Customize your online journal experience by signing up for e-mail alerts related to your subspecialty or area of interest. Access this free service by clicking on the "My Alerts" link on the home page. An extensive list of subspecialties, methods, and study design choices will be available for you to choose from-allowing you priority alerts to cutting-edge research in your field!

\section{Disputes \& Debates: Rapid online correspondence}

The editors encourage comments on recent articles through Disputes \& Debates:

Access an article at Neurology.org/ $\mathrm{N}$ and click on "MAKE COMMENT" beneath the article header. Responses will be posted as rapidly as possible.

Before submitting a comment to Disputes \& Debates, remember the following:

- Disputes \& Debates is restricted to comments about articles published in Neurology within the last 8 weeks

- Read previously posted comments; redundant comments will not be posted

- Your submission must be 200 words or less and have a maximum of 5 references; the first reference must be the article on which you are commenting

- You can include a maximum of 5 authors (including yourself) 


\section{Neurology}

Cervical Spondylotic Myelopathy Secondary to Ochronotic Vertebral Arthropathy

Wladimir Bocca Vieira de Rezende Pinto, Igor Braga Farias, Bruno de Mattos Lombardi Badia, et al.

Neurology 2021;96;627-628 Published Online before print February 10, 2021

DOI 10.1212/WNL.0000000000011663

This information is current as of February 10, 2021

\section{Updated Information \&} Services

References

Subspecialty Collections

Permissions \& Licensing

Reprints including high resolution figures, can be found at: http://n.neurology.org/content/96/13/627.full

This article cites 2 articles, 0 of which you can access for free at: http://n.neurology.org/content/96/13/627.full\#ref-list-1

This article, along with others on similar topics, appears in the following collection(s):

Disc disease

http://n.neurology.org/cgi/collection/disc_disease Metabolic disease (inherited)

http://n.neurology.org/cgi/collection/metabolic_disease_inherited

Information about reproducing this article in parts (figures,tables) or in its entirety can be found online at:

http://www.neurology.org/about/about_the_journal\#permissions

Information about ordering reprints can be found online:

http://n.neurology.org/subscribers/advertise

Neurology ${ }^{\circledR}$ is the official journal of the American Academy of Neurology. Published continuously since 1951, it is now a weekly with 48 issues per year. Copyright @ 2021 American Academy of Neurology. All rights reserved. Print ISSN: 0028-3878. Online ISSN: 1526-632X.

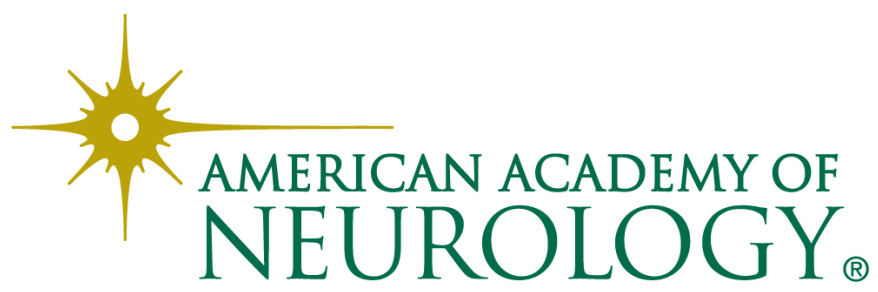

